\title{
Customer Loyalty in Digital Wallet Industry: the Role of Satisfaction, Effort Expectancy, Performance Expectancy, and Habit
}

\author{
Chyntia Sheila Elok, S.Kom. ${ }^{1}$ and Dr. Aprihatiningrum Hidayati, M.M.* \\ ${ }^{1}$ Department of Management, Sekolah Tinggi Manajemen PPM, Jakarta, Indonesia \\ 2 Department of Management, Sekolah Tinggi Manajemen PPM, Jakarta, Indonesia \\ *Corresponding author: apr@ppm-manajemen.ac.id
}

\begin{abstract}
Due to the high market competition, customer loyalty becomes one of the biggest challenges in the digital wallet industry today. Therefore, it's important for business players to understand consumer behavior in using digital wallet, not only limited to the adoption or acceptance phase, but also the post-adoption phase including customer loyalty. The purpose of this research is to explore the roles of satisfaction, performance expectancy, effort expectancy, facilitating conditions, habit, and switching barriers in influencing customer loyalty. The research model was tested using 158 valid responses from an online survey conducted in Indonesia. This research is a collective research design (descriptive research). The research model has been estimated using Partial Least Squares Structural Equation Modeling (PLS-SEM) method. The results indicate that habit and satisfaction have a significant positive effect on customer loyalty. Besides that, satisfaction is proved as mediator with full mediation effect for performance expectancy and effort expectancy on indirect relations to customer loyalty. In this study, the facilitating conditions and switching barriers have no direct significant impact on customer loyalty. For researchers, this study complements previous research and deepens the theory of consumer behavior, specifically regarding customer loyalty in using digital wallet as mobile payment. For practitioners, the findings of this study can provide meaningful insights about customer loyalty or continuance usage behavior toward digital wallet or other financial technology to help develop effective business strategies.
\end{abstract}

\section{Research purpose:}

The purpose of this research is to explore the roles of satisfaction, performance expectancy, effort expectancy, facilitating conditions, habit, and switching barriers in influencing customer loyalty.

\section{Research motivation:}

Due to the high market competition, customer loyalty becomes one of the biggest challenges in the digital wallet industry today. Therefore, it's important for business player to understand consumer behavior in using digital wallet, not only limited to the adoption or acceptance phase, but also the post-adoption phase including customer loyalty.

\section{Research design, approach and method:}

The research model was tested using 158 valid responses from an online survey conducted in Indonesia. This research is a collective research design (descriptive research). The research model has been estimated using Partial Least Squares Structural Equation Modeling (PLS-SEM) method.

\section{Main findings:}

The research model has been estimated using Partial Least Squares Structural Equation Modeling (PLS-SEM) method. The results indicate that habit and satisfaction have a significant positive effect on customer loyalty. Besides that, satisfaction is proved as mediator with full mediation effect for performance expectancy and effort expectancy on indirect relations to customer loyalty. In this study, the facilitating conditions and switching barriers have no direct significant impact on customer loyalty.

\section{Practical/managerial implications:}

For researchers, this study complements previous research and deepens the theory of consumer behavior, specifically regarding customer loyalty in using digital wallet as mobile payment. For practitioners, the findings of this study can provide meaningful insights about customer loyalty or continuance usage behavior toward digital wallet or other financial technology to help develop effective business strategies.

Keywords: digital wallet, loyalty, satisfaction, performance expectancy, effort expectancy, habit 


\section{INTRODUCTION}

The COVID-19 pandemic has accelerated digital transformation in Indonesia. During the COVID-19 pandemic, the intensity of the internet and digital applications usage is getting higher. In the second quarter of 2020 , the number of internet users in Indonesia reached $73.7 \%$ of the Indonesian population or the equivalent of 196.7 million users (Asosiasi Penyelenggara Jasa Internet Indonesia, 2020). The largest internet users in Indonesia come from the Java Island, namely $56.4 \%$. According to Bank Indonesia (BI), the value of electronic money transactions reached IDR 204,9 trillion in 2020, growing by $41.2 \%$ from IDR 145,2 trillion in 2019 (Bank Indonesia, 2020).

In the midst of huge market opportunities, digital wallet competition in Indonesia is getting tougher along with the increasing number of Indonesian digital wallet players. Some of the popular digital wallet services in Indonesia namely Gopay, Ovo, Dana, LinkAja, and ShopeePay. The number of digital wallet causing low consumer loyalty to the brand. Moreover, each digital wallet has its own business and marketing strategy, including by offering attractive promotions and various excellent features.

In a study about continuance usage of mobile internet services, Zhou (2013) state that unless users continue their usage, mobile service providers cannot achieve success. Service providers have invested great resource and effort on releasing mobile services. They cannot recover costs and make profit if users discontinue their usage. Mobile service providers need to retain users in order to achieve competitive advantage. Acquiring new users is only the initial step for mobile service providers, they also need to retain existing users and facilitate their post-adoption usage.

There are several studies about consumer behavior of digital wallets in Indonesia, but many studies focus on early adoption and acceptance, while study about post-adoption is still limited, such as satisfaction and loyalty. Brand loyalty is a deeply rooted commitment to repurchase a product or repatronize a service in the future (Oliver, 1997). In this study, repurchase was defined as continuing to use the services of a digital wallet.

\section{Performance Expectancy, Effort Expectancy, and Customer Loyalty}

Performance expectancy is defined as the degree to which an individual believes that using the system will help him or her to attain gains in job performance (Venkatesh et al., 2003). According to his article about user acceptance of Information technology, Venkantest mentions there are five constructs from different models that pertain to performance expectancy, that's are perceived usefulness (TAM/TAM2), extrinsic motivation (MM), job-fit (MPCU), relative advanctage (IDT), and outcome expectations (SCT). While, Effort expectancy is defined as degree of ease associated with the use of the system. Three constructs from the existing models capture the concept of effort expectancy, that's are perceived ease of use (TAM/TAM2), complexity (MPCU), and easy of use (IDT). A research indicate that performance expectancy and effort expectancy are all significantly related to continuance intention (Lai \& Shi, 2015)

H1: Performance expectancy has a significant positive effect on the customer loyalty toward the usage of digital wallet.

H2: Effort expectancy has a significant positive effect on the customer loyalty toward the usage of digital wallet.

\section{Facilitating Conditions and Customer Loyalty}

Facilitating conditions refer to consumers' perceptions of the resources and support available to perform a behavior (Venkatesh et al., 2003, 2012). A study that examined consumer satisfaction, continues intention, and behavior toward apps shopping (Rezaei et al., 2016), found that facilitating condition has a positive impact on consumers' continuance intention and behavior. But, in another study, the result shows that facilitating conditions did not affect continuances usage significantly (Chopdar \& Sivakumar, 2018).

H3: Facilitating condition has a significant positive effect on the customer loyalty toward the usage of digital wallet.

\section{Habit and Customer Loyalty}

Habit is associated with a repeated behavior that has gained automatic qualities and that is performed under relatively stable conditions with a minimal focus of attention (Olsen et al., 2013; Ouellette \& Wood, 1998). As mentioned by Venkatesh et al. (2012), habit has been operationalized in two distinct ways: first, habit is viewed as prior behavior; and second, habit is measured as the extent to which an individual believes the behavior to be automatic. Repeat purchasers continue to buy (or use) the same brand though they do not have an emotional attachment to it, they may do so out of habit (Mothersbaugh \& Hawkins, 2016).

There are still limited studies that discuss the habit variable in relation to customer loyalty in the use of digital wallets or other financial technology. The finding of a study confirm habit as the foremost predictor of both continuance intention and usage (Chopdar \& Sivakumar, 2018). Ghazali (2011) in his study also stated that habit has positively correlated with continuance usage, "Habit or inertia is one of the constructs that is considered important in consumer 
behavior, and is closely associated with customer loyalty and retention".

H4: Habit has a significant positive effect on the customer loyalty toward the usage of digital wallet.

\section{Switching Barriers and Customer Loyalty}

Switching barriers represents any factor, which makes it more difficult or costly for consumers to change providers, supplier, vendor, store, etc (Claes Fornell, 1992; Jones et al., 2000). Jones et al. (2020) did a study to answer a question about why customers stay, they examined three such barriers, namely interpersonal relationships, perceived switching costs, and the attractiveness of competing alternatives. In their study, they stated that although core-service satisfaction was a critical determinant of retention, switching barriers were also found important. The effect of core-service satisfaction on repurchase intentions was reduced when customers perceived high switching barriers.

A study that has a purpose to develop a model which explains how the loyalty of individual users of online banking is formed, state that e-satisfaction, e-trust, and the switching barriers have a direct effect on e-loyalty (López-Miguens \& Vázquez, 2017). Another study found that satisfaction and switching barriers are positively related to customer loyalty; and the switching barriers have a stronger influence on customer loyalty compared with satisfaction. The same statement is also mentioned on the previous study, that's the satisfaction, trust and switching barriers have positive effect on loyalty (Liu et al., 2011).

H5: Switching barriers have a significant positive effect on the customer loyalty toward the usage of digital wallet.

\section{Satisfaction and Customer Loyalty}

There are some related study related about the relationship between satisfaction and customer loyalty on the use of digital wallet or another mobile payment. Satisfaction, trust, and the switching barriers have positive effect on loyalty (Liu et al., 2011; López-Miguens \& Vázquez, 2017). Similar result was found by Chuah et al. (2017) that indicates satiscation and switching barriers positively affect the customer loyalty. Phuong et al. (2020) did a study that has a purpose to identify antecedents of mobile wallet continuance intention in Vietnam. As a result of this study, the positive effects that satisfaction and trust have on electronic wallet continuance intention are confirmed.

H6: Customer Satisfaction has a significant positive effect on the customer loyalty toward the usage of digital wallet.

\section{Satisfaction as Mediator}

Some studies indicate that performance expectancy and effort expectancy positively affect the satisfaction (Chao, 2019; Phuong et al., 2020). A study examine the efficacy of UTAUT model (performance expectancy, effort expectancy, social influence, facilitating conditions) and the influencial role of satisfaction in technology acceptance and use (Bouznif, 2017). The results of this study indicate that satisfaction plays an essential role on the predication of continuance intention as an independent and mediating variable. However, performance expectancy, effort expectancy, and superior influence have no direct significant impact on continuance intention. The result indicated the powerful impact of satisfaction as a mediator on the relation between independent variables (performance expectancy and effort expectancy) and the continuous usage intention as dependent variable.

H7: Customer Satisfaction positively moderates the relationship between Perfomance Expectancy and Customer Loyalty toward the usage of digital wallet.

H8: Customer Satisfaction positively moderates the relationship between Effort Expectancy and Customer Loyalty toward the usage of digital wallet.

This study attempts to fill the gaps in existing literature and aims to further understand customer loyalty of digital wallet in Indonesia. The attributes identified in the study include customer loyalty, performance expectancy, effort expectancy, facilitating conditions, habit, switching barriers, and satisfaction.

\section{METHODOLOGY}

\subsection{Research Type}

This study uses a conclusive research design (descriptive) to examine the relationship between variables. The research uses a quantitative approach by using statistics for the analysis. The quantitative data is to determine the relationship between independent or exogenous variables (e.g. performance expectancy, effort expectancy, facilitating conditions, habit, switching barriers, and satisfaction) and the endogenous or dependent variable (e.g. customer loyalty). In this study, the roles of satisfaction is also as a mediator for performance expectancy and effort expectancy to customer loyalty.

\subsection{Data Collection Method}

The research data were gathered through an online survey using a google form platform. The questionnaire was distributed using the random sampling technique. The questions on the questionnaire consist of 10 sections:

1. Filtering questions to ensure adequecy of each respondent characteristics corresponding to research criterias, including: confirmation that the respondent uses a digital wallet; respondent is domiciled in Java Island, Indonesia (including Special Region of Yogyakarta and Jakarta).

2. Experience and behavior use, including: digital wallet platform used; digital wallet features used (e.g. online shopping, offline shopping, transportation, subscription payment, etc). 
3. Perfomance Expectancy Section

4. Effort Expectancy Section

5. Facilitating Conditions Section

6. Habit Section

7. Switching Barriers Section

8. Satisfaction Section

9. Customer Loyalty Section

The measurement item of this research were adopted from previously literature (refer to Appendix 1). Seven constructs (performance expectancy, effort expectancy, facilitating conditions, habit, switching barriers, satisfaction, and customer loyalty) were adapted from the instrument of (Chuah et al., 2017; López-Miguens \& Vázquez, 2017; Mtebe \& Raisamo, 2014; Oliveira et al., 2016; Soodan \& Rana, 2020; Venkatesh et al., 2012).

The questionnaire scale uses 5-point likert scale: strongly disagree; disagree; neither agree nor disagree; Agree; strongly agree.

\subsection{Data Analysis Method}

Data analysis in this study used the Partial Least Squares Structural Equation Modeling (PLS-SEM) method to measure the exogenous and endogenous variables. Fig. 1 shows the proposed model in this research.

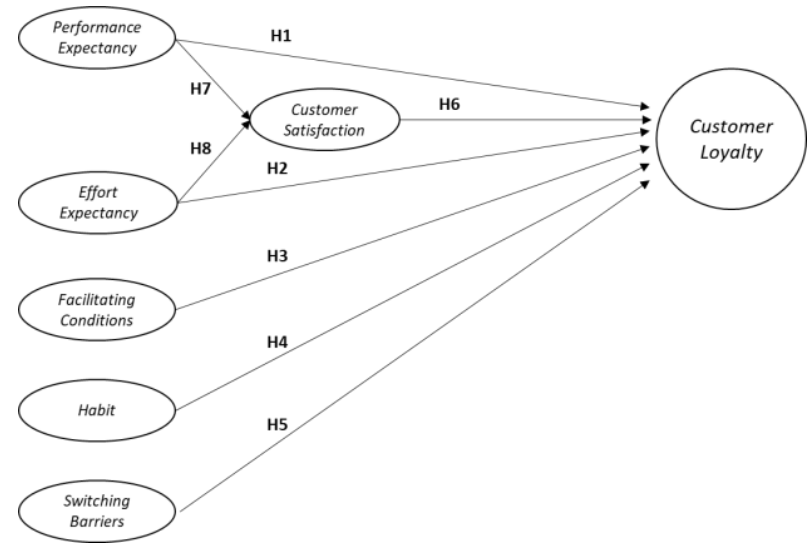

Fig. 1: Proposed Research Model

Sample size determination was performed by using suggestion of Cohen (1988) and Joe F. Hair et al. (2014) The research model has 5\% significant level, the minimum $\mathrm{R}^{2}$ value is 0.10 . Afterward, refer to Fig. 1, the maximum number of arrow pointing at a construct is six. Based on these parameters, the minimum sample size used in this study is 157 .

Table 1 shows parameters of measurement model and structural model from PLS-SEM method based on guideline from (Chin, 2010; Claes Fornell, 1992; Joseph F. Hair et al., 2019). The measurement model characteristics consist of reflective indicator loadings, internal consistency reliability, convergent validity, and discriminant validity (cross loading; Fornell Larcker Criterion). The structural model characteristic consist of path coefficient, significance, collinearity, coefficient of determination, and predictive relevance.
Table 1: Measurement Model and Structural Model from PLS-SEM Method

\begin{tabular}{lr}
\hline PARAMETER & STANDARD VALUE \\
\hline $\begin{array}{l}\text { Reflective indicator } \\
\text { loadings / Factor } \\
\text { Loadings }\end{array}$ & \\
\hline $\begin{array}{l}\text { Internal Consistency } \\
\text { Reliability }\end{array}$ & CR $>0.7$ \\
Convergent Validity & AVE $\geq 0.5$ \\
\hline $\begin{array}{l}\text { Discriminant Validity } \\
\text { Cross Loading }\end{array}$ & Square root AVE $>$ \\
\hline $\begin{array}{l}\text { Discriminant Validity } \\
\text { Fornell Larcker Criterion }\end{array}$ & correlation \\
\hline $\begin{array}{l}\text { Path Coefficient \& } \\
\text { Significance }\end{array}$ & P value $<5 \%(0.05) ;$ \\
Collinearity $(\mathrm{VIF})$ & $3-5:$ statistic $>1.96$ \\
\hline coritical \\
Coefficient of \\
determination $\left(\mathrm{R}^{2}\right)$
\end{tabular}

\section{RESULTS AND DISCUSSION}

\subsection{Sample Characteristic}

Fieldwork survey took place on July 2021, and 180 of questionnaires were collected. After data cleaning, there are 22 questionnaires didn't meet the research criteria or respondent characteristic. Thus, the final valid sample contains 158 questionnaires whose the respondents were existing users of digital wallets.

Table 2 shows the sample characteristics including the respondent's demographic profile. According to Table 2, the total valid respondents $(\mathrm{n}=158)$ are over 20 years old, in which the most coverage age of 25 to 34 years $(78.8 \%)$. Based on occupation, $84 \%$ of respondents in this study are employees (government or public employees). From the survey results, it was found that the largest percentage of respondents $(46.8 \%)$ uses at least 3 digital wallets, $40.5 \%$ of respondents uses 2 digital wallets, and $12.7 \%$ of respondents uses only 1 digital wallet platform. Ovo, GoPay, ShopeePay are the digital wallet platform with the most users, followed by Dana and LinkAja. Other digital wallets were listed, but had low user rates, namely iSaku (Indomaret Retail), Starbucks e-card, GoMobile (CIMB) and Sakuku (BCA).

Table 2: Sample Characteristics

\begin{tabular}{llr}
\hline PROFILE & CHARACTERISTICS & $\%$ \\
\hline \multirow{2}{*}{ Gender } & Male & $44.3 \%$ \\
\cline { 2 - 3 } & Female & $55.7 \%$ \\
\hline
\end{tabular}




\begin{tabular}{|c|c|c|}
\hline \multirow[t]{5}{*}{ Age } & $20-24$ у.о. & $8.9 \%$ \\
\hline & $25-29$ y.o. & $39.9 \%$ \\
\hline & $30-34$ y.o. & $34.8 \%$ \\
\hline & 35-39 у.о. & $5.1 \%$ \\
\hline & $>39$ y.o. & $12.5 \%$ \\
\hline \multirow[t]{5}{*}{ Occupation } & Employees & $84.8 \%$ \\
\hline & Entrepreneur & $6.3 \%$ \\
\hline & Housewife & $4.4 \%$ \\
\hline & Freelancer & $3.8 \%$ \\
\hline & Students & $0.6 \%$ \\
\hline \multirow{3}{*}{$\begin{array}{l}\text { Number of } \\
\text { Digital } \\
\text { Wallets that } \\
\text { respondents } \\
\text { use }\end{array}$} & Use 1 platform & $12.7 \%$ \\
\hline & Use 2 platforms & $46.8 \%$ \\
\hline & Use $\geq 3$ platforms & $40.5 \%$ \\
\hline \multirow{6}{*}{$\begin{array}{l}\text { Digital } \\
\text { Wallet } \\
\text { Platform }\end{array}$} & OVO & $28.9 \%$ \\
\hline & GoPay & $28.1 \%$ \\
\hline & ShopeePay & $22.0 \%$ \\
\hline & DANA & $10.2 \%$ \\
\hline & LinkAja & $6.7 \%$ \\
\hline & Other Platform & $3.5 \%$ \\
\hline \multirow{11}{*}{$\begin{array}{l}\text { Behavior } \\
\text { Use }\end{array}$} & Online Shopping / & $17.1 \%$ \\
\hline & $\begin{array}{l}\text { Marketplace } \\
\text { Offline Retail Payment }\end{array}$ & $15.1 \%$ \\
\hline & Transportation Service & $13.2 \%$ \\
\hline & Food Delivery Service & $15.6 \%$ \\
\hline & $\begin{array}{l}\text { Paying Bills of Top-up \& } \\
\text { Data Package }\end{array}$ & $11.2 \%$ \\
\hline & Delivery Service & $9.4 \%$ \\
\hline & $\begin{array}{l}\text { Paying Bills of Utilities } \\
\text { (Electricity, PDAM, etc) }\end{array}$ & $7.1 \%$ \\
\hline & $\begin{array}{l}\text { Digital Platform } \\
\text { Subscription }\end{array}$ & $5.0 \%$ \\
\hline & Pay Later & $2.5 \%$ \\
\hline & Investment & $2.3 \%$ \\
\hline & Other Feature & $1.4 \%$ \\
\hline
\end{tabular}

For the analysis of the data we have used SmartPLS 3 software. By using the primary data we have evaluated the measurement model structural model.

\subsection{Evaluation of Measurement Model}

The data obtained from the questionnaire was used to measure each variable in the study. The Measurement Model evaluates the measures to see the validity and reliability of the data. The validity test in this research are evaluated based on the Convergent Validity and Discriminant Validity using following parameters: Loading Factor, AVE, Fornell Larcker Criterion, and Cross Loading.

Confirmatory Factor Analysis (CFA) that was performed using the SmartPLS software to evaluate multi-item constructs. CFA used to determine the factor and factor loading of measured variables, and to confirm what is expected on the basic or pre-established theory (Statistics Solutions, 2021).

Factor loading or outer loading is the value generated by each indicator to measure the variable. Factor loading value should be $>0.7$ for confirmatory research (Chin, 2010). Based on the factor loading parameter, there are three indicators (CL6; SB2; SB3) that were excluded from this study because the loadings factor value of these indicators are less than 0.7. Table 3 shows the Factor Loading Matrix for PLS-SEM confirmatory factor analysis. The PLS-SEM confirmatory factor analysis and structural model with SmartPLS shown in Fig. 2.

Table 3: Factor Loading Matrix

\begin{tabular}{|c|c|c|c|c|c|c|c|}
\hline & CL & CS & $\mathrm{EE}$ & FC & HA & $\mathrm{PE}$ & SB \\
\hline CL1 & 0.859 & & & & & & \\
\hline CL2 & 0.887 & & & & & & \\
\hline CL3 & 0.895 & & & & & & \\
\hline CL4 & 0.764 & & & & & & \\
\hline CL5 & 0.735 & & & & & & \\
\hline CS1 & & 0.911 & & & & & \\
\hline $\mathrm{CS} 2$ & & 0.883 & & & & & \\
\hline $\mathrm{CS} 3$ & & 0.839 & & & & & \\
\hline CS4 & & 0.883 & & & & & \\
\hline EE1 & & & 0.828 & & & & \\
\hline EE2 & & & 0.885 & & & & \\
\hline EE3 & & & 0.853 & & & & \\
\hline EE4 & & & 0.897 & & & & \\
\hline FC1 & & & & 0.714 & & & \\
\hline FC2 & & & & 0.706 & & & \\
\hline FC3 & & & & 0.830 & & & \\
\hline FC4 & & & & 0.750 & & & \\
\hline HA1 & & & & & 0.833 & & \\
\hline HA2 & & & & & 0.876 & & \\
\hline HA3 & & & & & 0.841 & & \\
\hline HA4 & & & & & 0.846 & & \\
\hline PE1 & & & & & & 0.819 & \\
\hline PE2 & & & & & & 0.787 & \\
\hline PE3 & & & & & & 0.789 & \\
\hline PE4 & & & & & & 0.879 & \\
\hline SB1 & & & & & & & 0.739 \\
\hline SB4 & & & & & & & 0.802 \\
\hline SB5 & & & & & & & 0.863 \\
\hline
\end{tabular}

Average Variance Extracted (AVE) is the value of every variable. The AVE should be $>0.5$, a variable with an AVE value below 0.5 represents an invalid indicator. Based on AVE value (Table 5), all variables in this research (CL, CS, EE, FC, HA, dan PE) are valid with AVE value is higher than 0.5 .

The Fornell Larcker Criterion was used for assessing the discriminant validity. Fornell \& Larcker, (1981) suggested that each construct's AVE should be higher than its squared correlation with any other construct. The Table 5 shows that all square root AVE is larger than any other correlations with other constructs. Cross Loading Criterion is the second option to measure the discriminant validity. Each indicator should load highest on the construct it is intented to measure (Chin, 2010). Refer to Appendix 2, each indicator loaded highest on the intended construct. Based on the Fornell Larcker Criterion and Cross Loading Criterion, all of variables on 
this research are valid.

The diagram in Fig. 2 shows the value of the path coefficient of each path, factor loading indicator values, and $\mathrm{R}^{2}$ values of the endogenous variables $(\mathrm{CS}, \mathrm{CL})$.

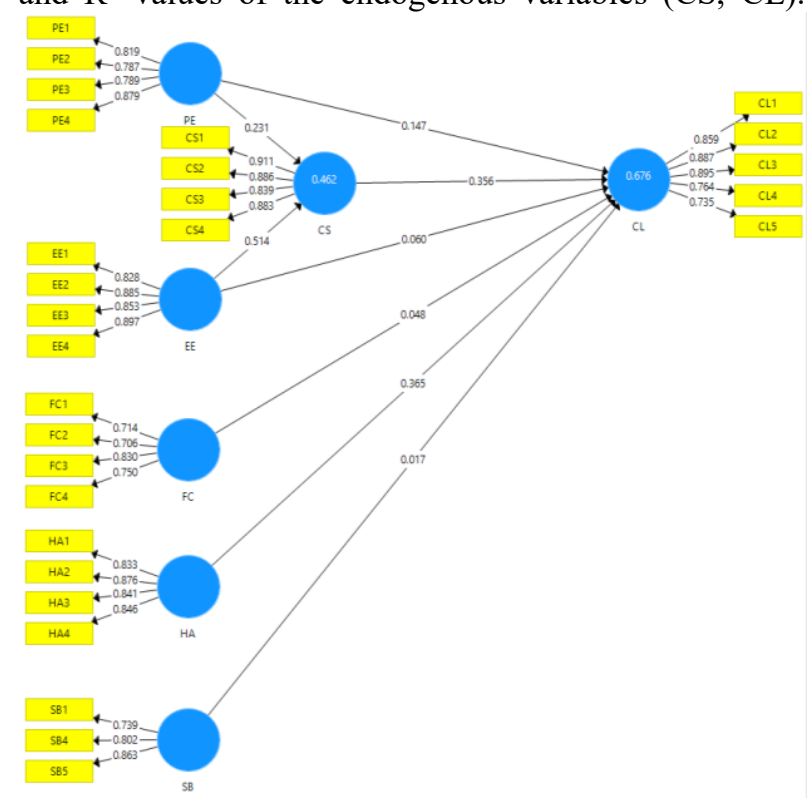

Fig. 2: PLS-SEM confirmatory factor analysis and structural model with SmartPLS.

\subsection{Evaluation of Structural Model}

The evaluation of structural model stage is based on the value of Coefficient of Dertermination, Path Coefficient, Significance, Predictive Relevance, and Indirect Effect. But, before assessing the structural relationships, collinearity must be examined to make sure it does not bias the regression results by calculating the VIF values (Hair et al., 2019). In this research model, the value of Collinearity (VIF) for each indicator is lower than 5 (refer to Table 7). It means there is no critical collinearity problem in the research model.

\section{Coefficient of Determinant $\left(\mathbf{R}^{\mathbf{2}}\right)$}

In this study, there are two endogenous variables, namely the Customer Loyalty (CL) and Customer Satisfaction (CS). The coefficient of determination $\left(\mathrm{R}^{2}\right)$ shows how much the exogenous variables affect the endogenous variables. Table 4 shows $\mathrm{R}^{2}$ value for Customer Loyalty (CL) and Customer Satisfaction (CS). $\mathrm{R}^{2}$ of CL variable is 0.676 or $67.6 \%$, CL variable was influenced $67.6 \%$ by eksogeneous variables (EE, FC, HA, PE, SB, CS). While, the R2 value of CS variable is 0.462 or $46.2 \%$, means there are $46.2 \%$ exogenous variables (EE and FC) influencing CS variable.

Table 4: Coefficient of Determination

\begin{tabular}{ccc}
\hline & R SQUARE & $\begin{array}{c}\text { R SQUARE } \\
\text { ADJUSTED }\end{array}$ \\
\hline CL & 0.676 & 0.663 \\
\hline CS & 0.462 & 0.455 \\
\hline
\end{tabular}


Table 5: Factor Loadings, CA, CR and AVE

\begin{tabular}{|c|c|c|c|c|c|}
\hline CONSTRUCTS & ITEMS & $\begin{array}{c}\text { FACTOR } \\
\text { LOADINGS }\end{array}$ & $\begin{array}{c}\text { CRONBACH'S } \\
\text { ALPHA }\end{array}$ & $\begin{array}{l}\text { COMPOSITE } \\
\text { RELIABILITY }\end{array}$ & AVE \\
\hline \multirow[t]{5}{*}{ Customer Loyalty (CL) } & CL1 & 0.859 & 0.885 & 0.917 & 0.690 \\
\hline & CL2 & 0.887 & & & \\
\hline & CL3 & 0.895 & & & \\
\hline & CL4 & 0.764 & & & \\
\hline & CL5 & 0.735 & & & \\
\hline \multirow[t]{4}{*}{ Customer Satisfaction (CS) } & CS1 & 0.911 & 0.903 & 0.932 & 0.775 \\
\hline & $\mathrm{CS} 2$ & 0.883 & & & \\
\hline & CS3 & 0.839 & & & \\
\hline & CS4 & 0.883 & & & \\
\hline \multirow[t]{4}{*}{ Effort Expectation (EE) } & EE1 & 0.828 & 0.889 & 0.923 & 0.750 \\
\hline & EE2 & 0.885 & & & \\
\hline & EE3 & 0.853 & & & \\
\hline & EE4 & 0.897 & & & \\
\hline \multirow[t]{4}{*}{ Facilitating Conditions (FC) } & $\mathrm{FC} 1$ & 0.714 & 0.745 & 0.838 & 0.565 \\
\hline & $\mathrm{FC} 2$ & 0.706 & & & \\
\hline & FC3 & 0.830 & & & \\
\hline & FC4 & 0.750 & & & \\
\hline \multirow[t]{4}{*}{ Habit (HA) } & HA1 & 0.833 & 0.871 & 0.912 & 0.721 \\
\hline & HA2 & 0.876 & & & \\
\hline & HA3 & 0.841 & & & \\
\hline & HA4 & 0.846 & & & \\
\hline \multirow[t]{4}{*}{ Perfomance Expectancy (PE) } & PE1 & 0.819 & 0.837 & 0.891 & 0.672 \\
\hline & PE2 & 0.787 & & & \\
\hline & PE3 & 0.789 & & & \\
\hline & PE4 & 0.879 & & & \\
\hline \multirow[t]{3}{*}{ Switching Barriers (SB) } & SB1 & 0.739 & 0.730 & 0.844 & 0.644 \\
\hline & SB4 & 0.802 & & & \\
\hline & SB5 & 0.863 & & & \\
\hline
\end{tabular}

Table 6: Inter-construct correlations and discriminant validity

\begin{tabular}{cccccccc}
\hline \multicolumn{1}{c}{ CL } & CS & EE & FC & HA & PE & SB \\
\hline CL & $\mathbf{0 . 8 3 1}$ & & & & & & \\
\hline CS & 0.710 & $\mathbf{0 . 8 8 0}$ & & & & & \\
\hline EE & 0.614 & 0.655 & $\mathbf{0 . 8 6 6}$ & & & & \\
\hline FC & 0.582 & 0.651 & 0.730 & $\mathbf{0 . 7 5 2}$ & & & \\
\hline HA & 0.714 & 0.550 & 0.527 & 0.471 & $\mathbf{0 . 8 4 9}$ & & \\
\hline PE & 0.642 & 0.544 & 0.610 & 0.560 & 0.648 & $\mathbf{0 . 8 1 9}$ & \\
\hline SB & 0.150 & 0.114 & 0.170 & 0.232 & 0.180 & 0.031 & $\mathbf{0 . 8 0 3}$ \\
\hline
\end{tabular}

Table 7: Collinearity (VIF)

\begin{tabular}{clclcccc}
\hline Indicator & VIF & Indicator & VIF & Indicator & VIF & Indicator & VIF \\
\hline CL1 & 3.381 & EE1 & 2.141 & HA1 & 2.261 & SB1 & 1.243 \\
\hline CL2 & 4.189 & EE2 & 2.647 & HA2 & 2.872 & SB4 & 1.811 \\
\hline CL3 & 3.709 & EE3 & 2.376 & HA3 & 2.546 & SB5 & 1.700 \\
\hline CL4 & 1.736 & EE4 & 2.962 & HA4 & 2.226 & & \\
\hline CL5 & 1.596 & FC1 & 1.488 & PE1 & 1.905 & & \\
\hline CS1 & 3.135 & FC2 & 1.368 & PE2 & 1.837 & & \\
\hline CS2 & 2.804 & FC3 & 1.749 & PE3 & 1.655 & & \\
\hline CS3 & 2.210 & FC4 & 1.336 & PE4 & & & \\
\hline CS4 & 2.699 & & &
\end{tabular}




\section{Path Coefficient}

Path coefficient indicates the direct effect of a variable assumed to be a cause on another variable assumed to be an effect. Researchers need to run bootstrapping to assess the path coefficients' significance and evaluate their values, which typically fall in the range of -1 and +1 (Hair et al., 2019). A variable has a positive direction, if the path coefficient value is in the range 0 to 1 . Table 8 shows each variable in this research model have a proper value. Thus, each hypothesis in this study is positive or in other words the relationship between variables positively affects other variables.

Table 8: Path Coefficients

\begin{tabular}{|c|c|c|}
\hline & $\mathrm{CL}$ & $\mathrm{CS}$ \\
\hline \multicolumn{3}{|l|}{ CL } \\
\hline $\mathrm{CS}$ & 0.356 & \\
\hline $\mathrm{EE}$ & 0.060 & 0.514 \\
\hline $\mathrm{FC}$ & 0.048 & \\
\hline HA & 0.365 & \\
\hline $\mathrm{PE}$ & 0.147 & 0.231 \\
\hline SB & 0.017 & \\
\hline
\end{tabular}

The diagram in Fig. 2 shows the value of the path coefficient of each path, outer loading indicator values, and $\mathrm{R}^{2}$ values of the endogenous variables $(\mathrm{CS}, \mathrm{CL})$.

\section{Significance}

The final step is to assess the statistical significance. Significance is used to see the significance of each relationship between variables. Significance is obtained by finding the t-statistic value through the bootsrapping procedure with 5000 samples and 95\% confidence interval, the t-statistic values should higher than 1.96. Bootsrapping was applied for the significant of the path coefficient with two tails of $5 \%$, there are four variable relationships that have t-statistics above 1.96 , i.e. CS $\rightarrow$ $\mathrm{CL}, \mathrm{EE} \rightarrow \mathrm{CS}, \mathrm{HA} \rightarrow \mathrm{CL}$, and $\mathrm{PE} \rightarrow \mathrm{CS}$. While the relationship of other variables does not meet the requirements (less than 1.96). Refer to Table 9 to see the Signficanse values.

Table 9: Significance (t-statistic)

\begin{tabular}{lcccc}
\hline & $\begin{array}{c}\text { Sample } \\
\text { Mean }\end{array}$ & STDEV & $\begin{array}{c}\text { T } \\
\text { Statistics }\end{array}$ & P Values \\
\hline $\mathrm{CS} \rightarrow \mathrm{CL}$ & 0.359 & 0.084 & 4.242 & 0.000 \\
\hline $\mathrm{EE} \rightarrow \mathrm{CL}$ & 0.046 & 0.089 & 0.678 & 0.498 \\
\hline $\mathrm{EE} \rightarrow \mathrm{CS}$ & 0.513 & 0.076 & 6.777 & 0.000 \\
\hline $\mathrm{FC} \rightarrow \mathrm{CL}$ & 0.051 & 0.068 & 0.710 & 0.478 \\
\hline $\mathrm{HA} \rightarrow \mathrm{CL}$ & 0.364 & 0.071 & 5.114 & 0.000 \\
\hline $\mathrm{PE} \rightarrow \mathrm{CL}$ & 0.154 & 0.087 & 1.693 & 0.091 \\
\hline $\mathrm{PE} \rightarrow \mathrm{CS}$ & 0.232 & 0.074 & 3.110 & 0.002 \\
\hline $\mathrm{SB} \rightarrow \mathrm{CL}$ & 0.030 & 0.047 & 0.369 & 0.712 \\
\hline
\end{tabular}

Predictive relevance $\left(\mathrm{Q}^{2}\right)$ measures how well the observed values generated by the model and the estimated parameters are. The cross validated redundancy as a memasure of $\mathrm{Q}^{2}$ is recommended because it includes the key element of the path model, the structural model, to predict eliminated data points
(Chin, 2010; Choi, 2017). The observation value is considered good if the Q2 value is above 0 . The value of $\mathrm{Q}^{2}$ on CL (0.441) and CS (0.346) is at the medium level of prediction accuracy. It means the research model has a good observation value.

\subsection{Testing of Mediation Effect}

In this research model, the Customer Satisfaction variable is also as mediator in the relationship between Effort Expectation and Customer Loyalty; and the relationship between Performance Expectancy and Customer Loyalty. In the evaluation of Significance, (t-statistics) for direct effects, it was found that both of Effort Expectation (EE) and Perfomance Expectancy (PE) have no significant effect on Customer Loyalty (CL). The assessment of mediation effect is perfomed by looking at the change in Significance (t-statistics) on the indirect effect

Table 10 shows t-statistic value of the specific indirect effect. T-statistic value of PE $\rightarrow$ CL path changes from 0.082 to 2.269 when using the mediator ( $\mathrm{PE} \rightarrow \mathrm{CS} \rightarrow$ $\mathrm{CL})$. T-stastic value of $\mathrm{EE} \rightarrow \mathrm{CL}$ path changes from 0.183 to 3.696 when using the mediator (EE $\rightarrow \mathrm{CS} \rightarrow$ CL). This value meets the criteria for significance, that's the t-statistic should be higher than 1.96. This result indicates that the CS variable has a significant influence on the relationship between PE and CL; as well as EE and CL.

Table 10: Specific Indirect Effect

\begin{tabular}{lcccc}
\hline & $\begin{array}{c}\text { Original } \\
\text { Sample }\end{array}$ & $\begin{array}{c}\text { Sample } \\
\text { Mean }\end{array}$ & $\begin{array}{c}\mathrm{T} \\
\text { Statistics }\end{array}$ & $\begin{array}{c}\mathrm{P} \\
\text { Values }\end{array}$ \\
\hline $\mathrm{PE} \rightarrow \mathrm{CS} \rightarrow \mathrm{CL}$ & 0.082 & 0.084 & 4.242 & 2.269 \\
\hline $\mathrm{EE} \rightarrow \mathrm{CS} \rightarrow \mathrm{CL}$ & 0.183 & 0.184 & 0.678 & 3.696 \\
\hline
\end{tabular}

\subsection{Finding Result}

Based on the evaluation of model structural, including Determinant Coefficient (R2), Path Coefficient, and Significance (t-statistics), the following conclusions are obtained (refer to Table 11 and Table 12). Overall, the accepted hypotheses in this study are $\mathrm{H} 4, \mathrm{H} 6, \mathrm{H} 7$, and H8.

Table 11: Hypotesis Test Result (H1-H6)

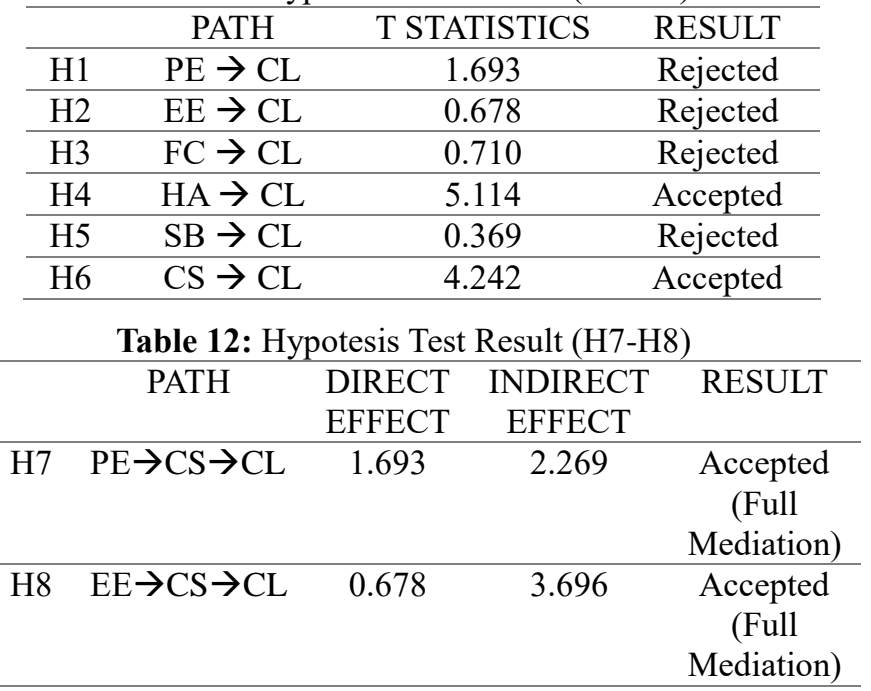


The result of the research model analysis indicates that there are two variables that have a significant positive effect on customer loyalty using digital wallets, i.e. satisfaction and habit. Habit found as the highest variable that has a positive effect on customer loyalty, this finding consistent with the previous study by Chopdar \& Sivakumar (2018) that also confirms habit as the foremost predictor of continuance intention and usage. As for satisfaction, the results of this study support several other studies which state that satisfaction has a positive effect on customer loyalty (Chuah et al., 2017; Liu et al., 2011; López-Miguens \& Vázquez, 2017; Phuong et al., 2020).

Chuah et al. (2017) and (López-Miguens \& Vázquez, 2017), in their study also states that the switching barriers factors positively related to customer loyalty, but in this study the switching barriers cannot be proven to have an significant effect on customer loyalty.

Another variable that is not proven to have a significant effect on customer loyalty is the facilitating condition. This result is contrary to the finding result by Rezaei et al. (2016) which found that facilitating condition has a positive impact on consumers' continuance intention and behavior. However, this research finding (about facilitating conditions) are in line with the previous research by Chopdar \& Sivakumar (2018) which states that facilitating conditions do not significantly affect sustainable use.

In this study, performance expectancy and effort expectancy were not found to have a significant effect in a direct relationship to customer loyalty. This result is contrary to the previous studies which states that performance expectancy and effort expectancy are significantly related to continuance intentions (Lai \& Shi, 2015; T. Zhou, 2013). However, this study found that satisfaction plays an essential role on the predication of costumer loyalty as a mediating variable for performance expectancy and effort expectancy. This result support the previos research of Bouznif (2017) which states that satisfaction plays an important role in the prediction of continouance intention as an independent and mediating variable for several variables including performance expectancy and effort expectancy.

\subsection{Theorical and Managerial Implications}

The research findings can deepen the marketing theory related to consumer behavior, specifically in customer loyalty in the use of digital wallets. Research findings related to the significant effect between habit factors on customer loyalty reinforce the study findings by Chopdar (2018), Amoroso (2017), and Ghazali (2011) which also found a positive relationship between habit and customer loyalty. Ghazali (2011) in his research suggests that habit is an important factor in consumer behavior and is closely related to customer loyalty and retention, "Habit or inertia is one of the constructs that is considered important in consumer behaviour, and is closely associated with customer loyalty and retention".
The results of this study also support the theory of Hawkins (2016) which states that the repeat purchasers are buying the brand out of habit.

In this study, it was also found that satisfaction plays an important role in the predication of customer loyalty as an independent and mediating variable. Satisfaction as an independent variable has a significant effect on customer loyalty, and has a major influence as a mediating variable (full mediation) for the relationship between performance expectancy and effort expectancy on customer loyalty. This finding supports the research of Bouznif (2017) which examines the relationship between some variables in the influence of satisfaction as a mediation, two of the variables are performance expectancy and effort expectancy. In addition, the results of this study enforce the theory of Kotler (2016) that states that in postpurchase actions, a satisfied consumer is more likely to purchase the product again and will also tend to say good things about the brand to others.

In managerial implication, this research contributes insight to the business player regarding the consumer behavior using digital wallet in relation to the factors that affect customer loyalty. The most important factor that needs to be considered by business player in increasing customer loyalty is the habit. In this study it was found that habit has a significant effect on customer loyalty. The second factor that becomes the driving factor in customer loyalty is customer satisfaction. Therefore, it is important for business player to invest in programs or innovations to increase customer satisfaction. Many aspects affect satisfaction, in this study performance expectancy and effort expectancy proved to have a significant effect on satisfaction, and also have an indirect affect on customer loyalty.

\section{CONCLUSION}

This study is intended to investigate the factors that can affect digital wallet customer loyalty. The results indicate that first, habit and satisfaction are significant positively related to customer loyalty; second, habit has a stronger influence on customer loyalty compared with other factors; third, satisfaction plays an essential role on the predication of customer loyalty as an independent and mediating variable. In this study, performance expectancy, effort expectancy, facilitating conditions, and switching barriers have no direct significant effect on customer loyalty.

This study has several limitations. This study has several limitations. First, data sources of the respondents were only limited to some areas in Indonesia. This limitation needs to be noted if anyone wants to use the results of the study as an overview of the Indonesian population, because this study does not analyze the different regions in Indonesia that have various cultures and differences in facility conditions that might affect the research. Further research can analyze the demographic characteristics of the region by looking at cultural, social or facility conditions. The 
second limitation is the variance of the variables analyzed in the study.

The second limitation is the variance of the variables analyzed in the study. The results show that $67.6 \%$ of customer loyalty were influenced by the variables examined in this study, it means that there are still around $32 \%$ of other factors outside the study that might affect customer loyalty. Refer to study of Komba \& Razak (2021); (Phuong et al., 2020); and (W. Zhou et al., 2018) the brand image and trust can be another factors that might be used in relation to consumer loyalty in the future study. Third, the analysis of the indirect effect on customer loyalty only takes satisfaction as a mediator. Further research can use other variables as mediators such as habit (Olsen et al., 2013) and trust (W. Zhou et al., 2018).

\section{ACKNOWLEDGMENTS}

Special thanks and gratitude are attached to Dr. Aprihatiningrum Hidayati, M.M who supervised this research. The work was supported by Sekolah Tinggi Manajemen PPM (Indonesia).

\section{REFERENCES}

[1] Asosiasi Penyelenggara Jasa Internet Indonesia. (2020). Laporan Survei Internet APJII 2019 2020. In Asosiasi Penyelenggara Jasa Internet Indonesia (Vol. 2020). https://apjii.or.id/survei

[2] Bank Indonesia. (2020). Transaksi Uang Elektronik. Https://Www.Bi.Go.Id/. https://www.bi.go.id/id/statistik/ekonomi-keua ngan/ssp/uang-elektronik-transaksi.aspx

[3] Bouznif, M. M. (2017). Business Students' Continuance Intention toward Blackboard Usage: An Empirical Investigation of UTAUT Model. International Journal of Business and Management, $13(1), \quad 120$. https://doi.org/10.5539/ijbm.v13n1p120

[4] Chao, C. M. (2019). Factors determining the behavioral intention to use mobile learning: An application and extension of the UTAUT model. Frontiers in Psychology, 10(JULY), 1-14. https://doi.org/10.3389/fpsyg.2019.01652

[5] Chin, W. W. (2010). How to write up and report PLS analyses. In Handbook of Partial Least Squares (pp. 655-690).

[6] Choi, J. (2017). PLS-SEM Guideline and Compliance https://leadershipcenter.tistory.com/441

[7] Chopdar, P. K., \& Sivakumar, V. J. (2018). Understanding continuance usage of mobile shopping applications in India: the role of espoused cultural values and perceived risk. Behaviour and Information Technology, 38(1), 42-64.

https://doi.org/10.1080/0144929X.2018.15135 63

[8] Chuah, S. H. W., Rauschnabel, P. A., Marimuthu, M., Thurasamy, R., \& Nguyen, B. (2017). Why do satisfied customers defect? A closer look at the simultaneous effects of switching barriers and inducements on customer loyalty. Journal of Service Theory and Practice, 27(3), 616-641. https://doi.org/10.1108/JSTP-05-2016-0107

[9] Cohen, J. (1988). Statistical Power Analysis for the Behavioral Sciences. Statistical Power Analysis for the Behavioral Sciences, 273-406. https://doi.org/10.4324/9780203771587

[10] Fornell, C., \& Larcker, D. F. (1981). SEM with Unobservable Variables and Measurement Error: Algebra and Statistics. In Journal of Marketing Research (Vol. 18, Issue 3, pp. 116).

[11]Fornell, Claes. (1992). Satisfaction Barometer: The Swedish Experience. Journal of Marketing, $56(1)$, 6-21. http://www.jstor.org/stable/1252129

[12] Ghazali, E. (2011). Customer Perceived Switching Barriers and Their Impact on Loyalty and Habitual Repurchase: A Study of Pure-Play Online Retailers in the UK. July. http://wrap.warwick.ac.uk/47650/1/WRAP_TH ESIS_Ghazali_2011.pdf

[13] Hair, Joe F., Sarstedt, M., Hopkins, L., \& Kuppelwieser, V. G. (2014). Partial least squares structural equation modeling (PLS-SEM): An emerging tool in business research. European Business Review, 26(2), 106-121. https://doi.org/10.1108/EBR-10-2013-0128

[14] Hair, Joseph F., Risher, J. J., Sarstedt, M., \& Ringle, C. M. (2019). When to use and how to report the results of PLS-SEM. European Business Review, 31(1), 2-24. https://doi.org/10.1108/EBR-11-2018-0203

[15] Jones, M. A., Mothersbaugh, D. L., \& Beatty, S. E. (2000). Switching barriers and repurchase intentions in services. Journal of Retailing, 76(2), 259-274. https://doi.org/10.1016/S0022-4359(00)000245

[16]Komba, K. J., \& Razak, K. A. (2021). Factors Influencing Customer Retention for Electronic Wallet Services in Malaysia. International Journal of Social Science and Humanity, 11(2), 44-47. https://doi.org/10.18178/ijssh.2021.v11.1037

[17] Lai, I. K. W., \& Shi, G. (2015). The impact of privacy concerns on the intention for continued use of an integrated mobile instant messaging and social network platform. International Journal of Mobile Communications, 13(6), 641-669. https://doi.org/10.1504/IJMC.2015.072086

[18]Liu, C. T., Guo, Y. M., \& Lee, C. H. (2011). The effects of relationship quality and switching barriers on customer loyalty. International Journal of Information Management, $\quad 31(1), \quad 71-79$. 
https://doi.org/10.1016/j.ijinfomgt.2010.05.008

[19] López-Miguens, M. J., \& Vázquez, E. G. (2017). An integral model of e-loyalty from the consumer's perspective. Computers in Human Behavior, 72, 397-411. https://doi.org/10.1016/j.chb.2017.02.003

[20] Mothersbaugh, D. L., \& Hawkins, D. I. (2016). Consumer Behavior: Building Marketing Strategy, Thirteenth Edition. In Mc Graw Hill Education https://books.google.co.in/books/about/Consu mer_Behavior.html?id=I54rAQAAMAAJ\&pgi $\mathrm{s}=1$

[21] Mtebe, J. S., \& Raisamo, R. (2014). Investigating students' behavioural intention to adopt and use mobile learning in higher education in East Africa. International Journal of Education and Development Using Information and Communication Technology (IJEDICT), 10(3), 4-20. http://files.eric.ed.gov/fulltext/EJ1059061.pdf

[22] Oliveira, T., Thomas, M., Baptista, G., \& Campos, F. (2016). Mobile payment: Understanding the determinants of customer adoption and intention to recommend the technology. Computers in Human Behavior, 61(2016), 404-414. https://doi.org/10.1016/j.chb.2016.03.030

[23] Oliver, R. L. (1997). Satisfaction: A behavioral perspective on the consumer. New York: Irwin/McGraw-Hill.

[24] Olsen, S. O., Tudoran, A. A., Brunsø, K., \& Verbeke, W. (2013). Extending the prevalent consumer loyalty modelling: The role of habit strength. European Journal of Marketing, 47(1), 303-323. https://doi.org/10.1108/03090561311285565

[25] Ouellette, J. A., \& Wood, W. (1998). Habit and Intention in Everyday Life: The Multiple Processes by Which Past Behavior Predicts Future Behavior. Psychological Bulletin, 124(1), 54-74. https://doi.org/10.1037/0033-2909.124.1.54

[26] Phuong, N. N. D., Luan, L. T., Dong, V. Van, \& Khanh, N. L. N. (2020). Examining customers' continuance intentions towards e-wallet usage: The emergence of mobile payment acceptance in Vietnam. Journal of Asian Finance, Economics and Business, 7(9), 505-516. https://doi.org/10.13106/JAFEB.2020.VOL7.N O9.505

[27] Rezaei, S., Shahijan, M. K., Amin, M., \& Ismail, W. K. W. (2016). Determinants of App Stores Continuance Behavior: A PLS Path Modelling Approach. Journal of Internet Commerce, 15(4), 408-440. https://doi.org/10.1080/15332861.2016.125674 9

[28] Soodan, V., \& Rana, A. (2020). Modeling customers' intention to use e-wallet in a developing nation: Extending UTAUT2 with security, privacy and savings. Journal of Electronic Commerce in Organizations, 18(1), 89-114.

https://doi.org/10.4018/JECO.2020010105

[29] Statistics Solutions. (2021). Factor Analysis. https://www.statisticssolutions.com/free-resour ces/directory-of-statistical-analyses/factor-anal ysis/

[30] Venkatesh, V., Morris, M. G., Davis, G. B., \& Davis, F. D. (2003). User acceptance of information technology: Toward a unified view. MIS Quarterly: Management Information Systems, 27(3), 425-478. https://doi.org/10.2307/30036540

[31] Venkatesh, V., Thong, J. Y. L., \& Xu, X. (2012). Consumer Acceptance and Use of Information Technology: Extending the Unified Theory of Acceptance and Use of Technology. 36(1), 157178.

[32]Zhou, T. (2013). Examining continuance usage of mobile Internet services from the perspective of resistance to change. Information Development, $30(1)$, 22-31. https://doi.org/10.1177/0266666912468762

[33]Zhou, W., Tsiga, Z., Li, B., Zheng, S., \& Jiang, S. (2018). What influence users' e-finance continuance intention? The moderating role of trust. Industrial Management and Data Systems, $118(8)$, $1647-1670$ https://doi.org/10.1108/IMDS-12-2017-0602 
Appendix 1: Measurement Items

\begin{tabular}{|c|c|c|c|}
\hline LATEN VARIABLE & \multicolumn{2}{|c|}{ MEASUREMENT ITEM } & ADAPTED FROM \\
\hline \multirow{4}{*}{$\begin{array}{l}\text { Perfomance Expectancy } \\
\text { (PE) }\end{array}$} & PE1 & I find digital wallet useful in my daily life. & \multirow{4}{*}{$\begin{array}{l}\text { Soodan \& Rana } \\
(2020) \\
\text { Venkatesh et al. } \\
(2012)\end{array}$} \\
\hline & PE2 & $\begin{array}{l}\text { Using digital wallet increases my chances of attaining } \\
\text { my objectives. }\end{array}$ & \\
\hline & PE3 & $\begin{array}{l}\text { Using digital wallet helps me complete things more } \\
\text { quickly. }\end{array}$ & \\
\hline & PE4 & Use of digital wallet increases my productivity. & \\
\hline \multirow[t]{4}{*}{ Effort Expectancy (EE) } & EE1 & Learning how to use digital wallet is easy for me. & \multirow{4}{*}{$\begin{array}{l}\text { Venkatesh et al. } \\
\text { (2012) }\end{array}$} \\
\hline & EE2 & $\begin{array}{l}\text { My interaction with digital wallet clear and } \\
\text { understandable. }\end{array}$ & \\
\hline & EE3 & I find digital wallet easy to use. & \\
\hline & EE4 & $\begin{array}{l}\text { It is easy for me to become skillful at using digital } \\
\text { wallet. }\end{array}$ & \\
\hline \multirow[t]{4}{*}{$\begin{array}{l}\text { Facilitating Conditions } \\
\text { (FC) }\end{array}$} & FC1 & $\begin{array}{l}\text { I have the resources necessary to use digital wallet } \\
\text { (smartphone, internet, etc) }\end{array}$ & \multirow{4}{*}{$\begin{array}{l}\text { Oliveira et al. (2016) } \\
\text { Venkatesh et al. } \\
(2012) \\
\text { Mtebe \& Raisamo } \\
(2014)\end{array}$} \\
\hline & $\mathrm{FC} 2$ & I have the knowledge necessary to use digital wallet. & \\
\hline & FC3 & $\begin{array}{l}\text { Digital wallet is compatible with other technologies I } \\
\text { use (e-commerce, mobile banking, samsung / apple } \\
\text { pay, etc) }\end{array}$ & \\
\hline & FC4 & $\begin{array}{l}\text { A help is available when I get problem in using digital } \\
\text { wallet applications. }\end{array}$ & \\
\hline \multirow[t]{4}{*}{ Habit (HA) } & HA1 & The use of digital wallet has become a habit for me. & \multirow{4}{*}{$\begin{array}{l}\text { Soodan \& Rana } \\
(2020) \\
\text { Venkatesh et al. } \\
(2012)\end{array}$} \\
\hline & HA2 & I am addicted to using digital wallet. & \\
\hline & HA3 & I must use digital wallet. & \\
\hline & HA4 & Using digital wallet has become natural to me. & \\
\hline \multirow[t]{5}{*}{ Switching Barriers (SB) } & SB1 & $\begin{array}{l}\text { Switching to other digital wallet, causing significant } \\
\text { monetary costs. }\end{array}$ & \multirow{5}{*}{$\begin{array}{l}\text { Chuah et al. (2017; } \\
\text { López-Miguens \& } \\
\text { Vázquez (2017) }\end{array}$} \\
\hline & SB2 & $\begin{array}{l}\text { Switching to other digital wallet, take lots of effort } \\
\text { and time. } \rightarrow \text { (dropped) }\end{array}$ & \\
\hline & SB3 & $\begin{array}{l}\text { If I switched to other digital wallet, I am afraid that } \\
\text { the new digital wallet offers me a worse service. } \rightarrow \\
\text { (dropped) }\end{array}$ & \\
\hline & SB4 & $\begin{array}{l}\text { If I switched to other digital wallet, I would lose } \\
\text { certain advantages that I have acquired to date (points, } \\
\text { free services, subsidized, discount, etc.). }\end{array}$ & \\
\hline & SB5 & $\begin{array}{l}\text { Generally, it would be a disorder to change my digital } \\
\text { wallet. }\end{array}$ & \\
\hline \multirow[t]{4}{*}{$\begin{array}{l}\text { Customer Satisfaction } \\
\text { (CS) }\end{array}$} & $\mathrm{CS} 1$ & $\begin{array}{l}\text { I am very satisfied with my current digital wallet for } \\
\text { mobile payment service. }\end{array}$ & \multirow[t]{4}{*}{ Chuah et al. (2017) } \\
\hline & $\mathrm{CS} 2$ & $\begin{array}{l}\text { My current digital wallet always fulfils my } \\
\text { expectations for mobile payment service. }\end{array}$ & \\
\hline & $\mathrm{CS} 3$ & $\begin{array}{l}\text { Until now, my current digital wallet has never } \\
\text { disappointed me for mobile payment service. }\end{array}$ & \\
\hline & CS4 & $\begin{array}{l}\text { Overall, my mobile payment usage experience with } \\
\text { my current digital wallet is excellent. }\end{array}$ & \\
\hline \multirow[t]{6}{*}{ Customer Loyalty (CL) } & CL1 & I say positive things about my digital wallet to others. & \multirow{6}{*}{$\begin{array}{l}\text { López-Miguens \& } \\
\text { Vázquez (2017) }\end{array}$} \\
\hline & CL2 & I recommend using it to those who ask me for advice. & \\
\hline & CL3 & I encourage friends and family to use it. & \\
\hline & CL4 & $\begin{array}{l}\text { I consider my digital wallet as my first option to } \\
\text { mobile payment services. }\end{array}$ & \\
\hline & CL5 & $\begin{array}{l}\text { I will continue using the services of mobile payment } \\
\text { from my digital wallet in the future. }\end{array}$ & \\
\hline & CL6 & $\begin{array}{l}\text { I will continue to use my digital wallet even I have to } \\
\text { pay for this service. } \rightarrow \text { (dropped) }\end{array}$ & \\
\hline
\end{tabular}


Appendix 2: Cross Loadings Criterion

\begin{tabular}{|c|c|c|c|c|c|c|c|}
\hline & CL & CS & $\mathrm{EE}$ & $\mathrm{FC}$ & HA & PE & SB \\
\hline CL1 & 0.859 & 0.576 & 0.489 & 0.501 & 0.510 & 0.569 & 0.152 \\
\hline CL2 & $\mathbf{0 . 8 8 7}$ & 0.568 & 0.493 & 0.477 & 0.577 & 0.580 & 0.125 \\
\hline CL3 & 0.895 & 0.580 & 0.472 & 0.472 & 0.674 & 0.595 & 0.097 \\
\hline CL4 & 0.764 & 0.610 & 0.498 & 0.422 & 0.585 & 0.462 & 0.129 \\
\hline CL5 & 0.735 & 0.606 & 0.590 & 0.540 & 0.601 & 0.449 & 0.119 \\
\hline CS1 & 0.672 & 0.911 & 0.638 & 0.607 & 0.560 & 0.594 & 0.066 \\
\hline $\mathrm{CS} 2$ & 0.634 & 0.886 & 0.590 & 0.623 & 0.507 & 0.493 & 0.152 \\
\hline CS3 & 0.590 & 0.839 & 0.498 & 0.499 & 0.430 & 0.375 & 0.098 \\
\hline CS4 & 0.598 & 0.883 & 0.569 & 0.555 & 0.428 & 0.432 & 0.088 \\
\hline EE1 & 0.487 & 0.591 & 0.828 & 0.601 & 0.392 & 0.528 & 0.128 \\
\hline EE2 & 0.537 & 0.561 & 0.885 & 0.649 & 0.461 & 0.565 & 0.176 \\
\hline EE3 & 0.567 & 0.576 & 0.853 & 0.644 & 0.520 & 0.517 & 0.152 \\
\hline EE4 & 0.533 & 0.539 & 0.897 & 0.631 & 0.448 & 0.502 & 0.131 \\
\hline $\mathrm{FC} 1$ & 0.338 & 0.472 & 0.510 & 0.714 & 0.249 & 0.442 & 0.119 \\
\hline FC2 & 0.403 & 0.453 & 0.545 & 0.706 & 0.411 & 0.419 & 0.091 \\
\hline FC3 & 0.457 & 0.519 & 0.625 & 0.830 & 0.382 & 0.482 & 0.193 \\
\hline FC4 & 0.517 & 0.508 & 0.515 & 0.750 & 0.356 & 0.357 & 0.262 \\
\hline HA1 & 0.565 & 0.470 & 0.500 & 0.416 & 0.833 & 0.619 & 0.115 \\
\hline HA2 & 0.626 & 0.391 & 0.415 & 0.380 & 0.876 & 0.521 & 0.154 \\
\hline HA3 & 0.589 & 0.400 & 0.351 & 0.352 & 0.841 & 0.397 & 0.217 \\
\hline HA4 & 0.640 & 0.602 & 0.523 & 0.449 & 0.846 & 0.659 & 0.125 \\
\hline PE1 & 0.468 & 0.403 & 0.409 & 0.381 & 0.552 & 0.819 & -0.032 \\
\hline PE2 & 0.475 & 0.433 & 0.457 & 0.425 & 0.423 & 0.787 & 0.012 \\
\hline PE3 & 0.563 & 0.489 & 0.587 & 0.515 & 0.579 & 0.789 & 0.042 \\
\hline PE4 & 0.581 & 0.450 & 0.525 & 0.497 & 0.558 & 0.879 & 0.070 \\
\hline SB1 & 0.118 & 0.068 & 0.104 & 0.101 & 0.144 & 0.029 & 0.739 \\
\hline SB4 & 0.078 & 0.054 & 0.090 & 0.170 & 0.021 & -0.062 & 0.802 \\
\hline SB5 & 0.146 & 0.131 & 0.188 & 0.266 & 0.212 & 0.069 & 0.863 \\
\hline
\end{tabular}

